\title{
SCIENCE AND DEVELOPMENT IN CHILE
}

\author{
BY THE HON. DEAN RUSK \\ U.S. Secretary of State
}

When the United States pledged its commitment to the Alliance for Progress in 1961, it recognized the central part science and technology must play in the economic and social transformation envisaged under the Alliance. The experience of the first years of the Alliance has not lowered our assessment of the importance of science in this development process. But it has refined thinking on how science can most usefully spur economic growth.

In Latin America generally, scientific talent is limited in quantity-indeed only $2 \cdot 3$ per cent of the population is classified as professional or technical in any field. It has been necessary to establish priorities. This has led to extensive discussions between scientists and technologists, on one hand, and those responsible for allocating national resources on the other; and, as a rule, the result has been the sound conclusion that short-range scientific and technical projects, however interesting in and of themselves, are less urgent than research and teaching institutions capable of promoting science and technology. Much has been done, and is being done, in improving curricula, strengthening faculties, equipping laboratories with the most modern and sophisticated research devices, and providing interchanges between the United States and Latin American scientists.

There is general agreement, I believe, that most of the Latin American countries need to put more emphasis on improving their agriculture and on making their rural areas a more active market and stimulus for manufacturing. Indeed, this is true of most of the developing areas of the world. As I have recently pointed out, agricultural production in the developing areas, particularly in Asia and Latin America, is growing less rapidly than population $\rightarrow$ and if current trends continue, the point will not be too far off when world food stocks will simply not be enough to meet minimum needs in the deficit areas.

Although Chile has a rich agricultural potential, it has been a net importer of food for some years and now imports about 20 per cent, or 125 million dollars, of its food needs. Every dollar of increased food production has the potential of freeing a dollar of valuable foreign exchange to buy goods and services needed for Chilean development.

The Agricultural Development Project now being initiated in Chile is a good example of how applied science contributes to a total development strategy. This project seeks to increase farm production through research activity and improved rural education institutions. Closely correlated activities seek to stimulate food output and exports through changes in the agricultural credit and marketing systems and in overall national agricultural policy.

Another effective application of science to Chile's economic priorities is the Maule River Project, so reminiscent of the Tennessee Valley Authority development in the United States. By late 1967 a comprehensive regional development plan will be created for the Maule River Basin, to include an integrated and co-ordinated construction and financial schedule for individual projects. The multi-purpose water resource plan will include uses for agriculture, industry, power, recreation, flood control and conservation. Related projects will cover agrarian reform, transportation, marketing, education and training, housing, urban growth, community development and public health.

The Manpower and Educational Planning Project is a key to assuring that, in the future, human resources will make their optimum contribution to Chile's economic and social goals.

I believe these three projects, among the other technical assistance activities with which the United States is concerned in Chile, are excellent examples of the co-opera- tive endeavour the States share under the Alliance. They are being implemented by Chilean institutions in collaboration with the Chile-California Programme and the U.S. A.I.D. Mission in Santiago, with funds provided both by the Government of Chile and A.I.D., and they are utilizing more fully than ever before the scientific capability of Chile and the United States in the service of the former's economic and social development under the Alliance for Progress.

Co-operation between Chile and the United States extends over a wide range of scientific subjects, including the sleep-wakefulness mechanisms. This has a somewhat special appeal to me. I have been told that science may make it possible for us to get on with less sleep at night. As I remarked on another occasion, I know some government officials who, of necessity, have already made considerable progress in that direction.

I turn now to the second main discipline of these seminars-earth sciences.

The same force which caused so much destruction in Chile during 1960 manifested itself in Alaska only last year. This awesome power of Nature disdains international boundaries. Investigations carried out in Chile on earthquake-resistant construction can have universal application. Development of techniques and instrumentation which can sense the early on-rush of earthquakes is as important in the eastern hemisphere as in the western.

New techniques to determine the location and extent of as yet unfound ore deposits are of great significance in the economic development of a country such as Chile, which has potentially such a great mineral wealth. I understand that investigations of this type are being actively pursued by the Institute of Geologic Research.

Investigations in physical oceanography offer many potential benefits, such as harnessing the tides and ocean currents for power. Exploitation of the plant and animal resources of the sea promises, I think, even more rewarding benefits. In a world where much of the population goes to bed at night hungry, where protein deficiency is widespread, the potential benefits from harvesting the sources in the sea are spectacular. The successful conclusion of experiments now under way in Chile producing fish protein concentrate on a pilot-plant scale could be of far-reaching benefit to mankind. We need more research in methods of influencing the biological cycle of the sea and in techniques leading to farming fish rather than hunting them. Such programmes might pose a challenge for scientists in the Fish Development Institute in Chile.

Progress in any of these scientific fields depends not so much on dollars as on manpower. The necessity for the development of trained manpower, including scientists, is an essential component of Chile's goals. It will continue to receive close attention by Chilean authorities and the U.S. A.I.D. Mission.

Because of the particular importance of science and engineering in economic development, a special committee of the Pan-American Union has been set up to investigate the science and engineering education programmes in Latin America. Investigations have already been carried out in several countries, and for Chile they have now been completed.

Let a meeting of scientists from Chile and the United States, gathered within the spirit of hemispheric co-operation, be interpreted by all as a certain sign that we stand together, ready to attack any and all to overcome any scientific or technological obstacles in the path of the economic and social progress of the peoples of the New World. 